\title{
Handbook of Florida Water Regulation: Florida Watershed Restoration Act ${ }^{1}$
}

\author{
Michael T. Olexa, Luke D'Isernia, Laura Minton, Dulcy Miller, and Sarah Corbett ${ }^{2}$
}

\section{Preface}

This handbook is designed to provide an accurate, current, and authoritative summary of the principle Federal and Florida laws that directly or indirectly relate to agriculture. This handbook should provide a basic overview of the many rights and responsibilities that farmers and farmland owners have under both Federal and Florida laws as well as the appropriate contact information to obtain more detailed information. However, the reader should be aware that because the laws, administrative rulings, and court decisions on which this handbook is based are subject to constant revision, portions of this publication could become outdated at anytime. Several details of cited laws are also left out due to space limitations.

This handbook is distributed with the understanding that the authors are not engaged in rendering legal or other professional advice, and the information contained herein should not be regarded as a substitute for professional advice. This handbook is not all inclusive in providing information to achieve compliance with the Federal and Florida laws and regulations governing water protection. For these reasons, the use of these materials by any person constitutes an agreement to hold harmless the authors, the Florida Cooperative Extension Service, the Institute of Food and Agricultural Sciences, and the University of Florida for any liability claims, damages, or expenses that may be incurred by any person as a result of reference to or reliance on the information contained in this handbook.

\section{Overview}

The Florida Legislature enacted the Florida Watershed Restoration Act (FWRA) in 1999, to protect Florida's waters with the development of a Total Maximum Daily Load (TMDL) program for state ground and surface waters as required by the Clean Water Act (CWA). This TMDL program will protect these waters by coordinating the control of point source and non-point source pollution. FWRA also establishes a process to identify and list impaired waters throughout the state.

1. This is EDIS document FE608, a publication of the Food and Resource Economics Department, Florida Cooperative Extension Service, Institute of Food and Agricultural Sciences, University of Florida, Gainesville, FL. Published December 2005. Please visit the EDIS website at http://edis.ifas.ufl.edu.

2. Michael T. Olexa, Professor, Food and Resource Economics Department, Florida Cooperative Extension Service, Institute of Food and Agricultural Sciences, University of Florida, Gainesville, FL; Director, Agricultural Law Center, University of Florida, Gainesville, FL; and Chair, Agricultural Law Committee of The Florida Bar. Luke D'Isernia, former student (graduated cum laude in 2005), Levin College of Law, University of Florida, Gainesville, FL. Laura Minton, Attorney, Dean, Mead, Egerton, Bloodworth, Capouano, and Bozarth, Orlando, FL. Dulcy Miller, attorney, Foley and Lardner, LLP, Orlando, FL. Sarah Corbett, Attorney, Florida Second District Court of Appeal, Lakeland, FL.

The Institute of Food and Agricultural Sciences (IFAS) is an Equal Opportunity Institution authorized to provide research, educational information and other services only to individuals and institutions that function with non-discrimination with respect to race, creed, color, religion, age, disability, sex, sexual orientation, marital status, national origin, political opinions or affiliations. U.S. Department of Agriculture, Cooperative Extension Service, University of Florida, IFAS, Florida A. \& M. University Cooperative Extension Program, and Boards of County Commissioners Cooperating. Larry Arrington, Dean 
TMDL is the total of the individual discharge allocations for point sources and the discharge allocations for non-point sources and natural background.

\section{Who Enforces the FWRA?}

Under the FWRA, while the Department of Environmental Protection is the lead agency in establishing TMDLs, the primary enforcement power is actually split between the Department of Environmental Protection (DEP) and the Department of Agriculture and Consumer Services (DACS). The DEP is the lead agency for enforcing FWRA when addressing point source and non agricultural non-point source pollution. The DACS is the lead agency for enforcing FWRA when it comes to agricultural non-point source pollution.

FWRA is unique in the establishment of TMDLs because it allows the DEP to address TMDLs through a watershed management approach in which water resources are managed based on natural boundaries instead of political or regulatory boundaries.

\section{What Are the Duties of the DEP and DACS under FWRA?}

Under FWRA, the DEP is required to coordinate with the water mangement districts (WMD), DACS, Soil and Water Conservation Districts, environmental groups, regulated parties and local stakeholders during all phases of the TMDL process, which includes:

- The listing of waters for which TMDL assessments will be conducted.

- The assessment methodology for determining those waters which are impaired, which fail to met the water quality standards (WQS) assigned to those waters.

- The calculation methodology, including determining what information is required for the TMDL assessment, the acceptable methods of data collection, and analysis and quality control requirements.
- Pollution Load Reduction Goals ( PLRGs), implementation of basin action plans, implementation of the TMDLs, and the implementation and evaluation of best management practices (BMP) and temporary measures.

Concerning the assessment methodology, the DEP must adopt this methodology by rule. This rule must provide for consideration of whether WQSs are being exceeded based on credible data, studies, and reports. The rule must also set the following:

- Water quality sample collection and analysis requirements.

- Approved methodologies.

- Quality assurance and quality control protocols.

- Data modeling.

- Other appropriate water quality assessment measures.

Concerning the implementation of TMDLs, the DEP can do so under existing water quality protection programs which may include:

- Permitting and other existing regulatory programs, such as water quality based effluent limitations.

- Pollutant trading or other agreements.

- Public works including capital facilities.

- Land acquisition.

TMDLs may also be implemented through NDPES permit conditions that provide a compliance schedule.

Concerning the implementation and evaluation of BMPs and temporary measures, the DEP must consult with the appropriate WMD and interested parties to develop suitable temporary measures, BMPs, or other measures to achieve the level of pollution reduction established by the DEP for nonagricultural non-point pollutant sources. These practices and measures may be adopted by rule by the DEP and WMDs, and when adopted in this manner 
these practices and measures must be implemented by the parties responsible for the nonagricultural non-point source pollution.

The DACS may develop and adopt by rule suitable temporary measures, BMPs, or other measures to achieve the level of pollution reduction established by the DEP for agricultural pollutant non-point sources. The DACS must consult with the Department of Environmental Protection, the Department of Health, the water management districts, affected farmers, and environmental groups in this development process. These practices and measures may be implemented by those parties responsible for agricultural pollutant sources and the DEP, with the WMDs and DACS, assisting in the implementation.

\section{What Are the Requirements under FWRA?}

Point sources discharging pollutants into Florida waters need to have NPDES permits. The parties do not have to implement BMPs and temporary measures not adopted by rule, since they are voluntary. There are advantages to implementation of BMPs and temporary measures adopted by rule. If BMPS are adopted by rule and their effectiveness is verified by the DEP, then implementation will provide a presumption of compliance with state WQSs and a release from liability such that the DEP cannot institute proceedings against the owner of the source of pollution to recover costs or damages associated with the contamination of surface water or groundwater caused by the pollutant.

If parties discharge pollutants into Florida waters without NPDES permits and without implementing BMPs, then DEP can institute proceedings against the parties to recover costs or damages associated with the contamination of surface water or groundwater caused by the pollutant.

For more information on the duties of the DEP and DACS under FWRA, and FWRA requirements, please contact the DEP or the DACS.

\section{Source}

\author{
Chapter 403, Florida Statutes, Section 304.067
}

\section{Acknowledgments}

The authors are indebted to the personnel of both state and federal agencies who provided their time and advice in the preparation of this handbook. The authors are especially indebted to Richard Budell of the Office of Agricultural Water Policy of the Florida Department of Agriculture and Consumer Services for providing funds for the development of this publication. 